\title{
TMSCl-catalysed condensation of $\alpha$-diketone compounds with urea/thiourea derivatives under solvent-free conditions
}

\author{
AKBAR MOBINIKHALEDI* and ALIREZA KHAJEH AMIRI \\ Department of Chemistry, Faculty of Science, Arak University, P.O. Box 14335-186, Arak, Iran \\ e-mail: a-mobinikhaledi@araku.ac.ir
}

MS received 21 January 2013; revised 16 May 2013; accepted 18 June 2013

\begin{abstract}
An efficient, rapid and green synthesis of glycoluril, imidazolidine-2-one, imidazole-2-one and imidazole-2-thiol derivatives have been accomplished by the reaction of urea/thiourea derivatives and $\alpha$ diketone at $100^{\circ} \mathrm{C}$ in the presence of trimethylsilyl chloride (TMSCl) as Lewis acid catalyst under solvent-free conditions. This approach offers many advantages such as good product yields, various products, short reaction time, easy isolation of products, facile purification and environmentally benign reaction conditions.
\end{abstract}

Keywords. TMSCl; solvent-free; green chemistry; glycoluril; imidazolidine-2-one; imidazole-2-thiol.

\section{Introduction}

The development of the chemistry of N-heterocycles based on urea or thiourea such as glycolurils, imidazolidine2-ones, imidazole-2-ones, imidazolidine-2-thiones and imidazole-2-thiones is of great interest due to high physiological activity of these materials. ${ }^{1,2}$

Glycoluril as the simplest member of this class of heterobicyclic compounds was synthesized for the first time in the 19th century. ${ }^{3}$ Glycoluril and its derivatives are the subject of many studies because of their synthetic accessibility, hydrogen-bond donating/accepting ureidyl functionality, curved and rigid structure. ${ }^{4,5}$ Mebicar (2,4,6,8-tetramethyl glycoluril) as one of representatives of this class is used in medical practice as a day tranquillizer. ${ }^{6}$ The glycolurils have been received a great deal of attention due to their practical applications such as polymer crosslinking, fertilizers, crystal engineering, explosives, stabilizer of organic compounds against photodegradation, radio iodination agents for biomoleculs, combinatorial chemistry, catalysts, bleaching activators and as monomer in supramolecular chemistry. ${ }^{7,8}$ In this study, by condensation reaction of $\alpha$-diketone with urea under acidic conditions, glycoluril was prepared as the only product, while under alkaline conditions hydantoin and glycoluril were obtained as the major and minor products, respectively. ${ }^{4}$

Imidazolidine-2-ones, imidazole-2-ones, imidazole2-thiones and imidazolidine-2-thiones are important

*For correspondence heterocycles with an embedded cyclic urea/thiourea scaffold, which is a core element of many pharmaceutically relevant compounds. ${ }^{9}$ They can exhibit a wide range of biological activities including inhibitions of the respiratory syncytial virus (RSV) fusion and NNRT (the nonnucleoside reverse transcriptase). ${ }^{10}$ Furthermore, these materials play important roles as progesterone receptor antagonists in the selective inhibition of farnesyltransferase (FTase) and the activation of $\mathrm{K}^{+}$channels. ${ }^{11}$ Among imidazolidine-2-ones, diphenin is known as antiepileptic drug. ${ }^{12}$

A number of methods for the synthesis of these materials have been reported. ${ }^{13-23}$ However, some of these pathways suffer from various drawbacks such as tedious work-up, unsatisfactory yields, refluxing for long periods with high boiling solvents. The aim of this work is to synthesize some glycoluril derivatives, imidazolidine-2-ones, imidazole-2-ones and imidazole2-thiol in the presence of TMSCl (trimethylsilyl chloride) under solvent-free conditions.

\section{Experimental}

IR spectra were prepared on a galaxy series FT-IR 5000 spectrophotometer using $\mathrm{KBr}$ discs. ${ }^{1} \mathrm{H}$ NMR and ${ }^{13} \mathrm{C}$ NMR spectra were obtained in DMSO- $d_{6}$ using Brucker spectrophotometer (300 MHz). Chemical shifts were expressed in (ppm) downfield from TMS. Melting points were determined using an electrothermal digital apparatus and are uncorrected. All chemical including urea/thiourea derivatives, benzil, trimethylsilyl chloride 
(known as TMSCl), (2-hydroxyethyl) trimethylammonium chloride (known as choline chloride) and solvents were commercially available and purchased from Merck or Fluka company and used without further purification. Water and other solvents were distilled before use.

2.1 General procedure for the synthesis of glycoluril, imidazolidine-2-one, imidazole-2-one, and imidazole-2-thiol derivatives

A mixture of $\alpha$-diketone $(1 \mathrm{mmol})$ and one of the urea or thiourea derivatives $(1.5 \mathrm{mmol})$ in $\mathrm{TMSCl}$ $(10 \mathrm{~mol} \%)$ was added into a test tube with a magnetic stirring bar. The test tube was heated in an oil bath at $100^{\circ} \mathrm{C}$ for $30 \mathrm{~min}$ and then was slowly cooled to room temperature and a mixture of hot EtOH- $\mathrm{H}_{2} \mathrm{O}(5: 5 \mathrm{~mL})$ added slowly and filtered off to extract the product. For most of the reactions purification was not necessary and the products were analysed by ${ }^{1} \mathrm{H}-\mathrm{NMR}$ spectroscopy and melting point. However, appropriate recrystallization in diethyl ether was used for further purification. All compounds were characterized on the basis of their spectroscopic data (IR, NMR) and melting point by comparison with those reported in the literature. ${ }^{11,12,17,19}$

2.1a Tetrahydro-3a,6a-diphenylimidazo[4,5-d] imidazole2,5(1H,3H)-dione (table 2, entry 1): Yield $0.21 \mathrm{~g}$ (72\%), m.p $>300^{\circ} \mathrm{C}$, IR $\left(\mathrm{KBr}, \mathrm{cm}^{-1}\right): 1687,1710$, 2847, 3070, 3230; ${ }^{1} \mathrm{H}$ NMR (300 MHz, DMSO- $\left.d_{6}\right): \delta$ 7.05-7.07 (10H, m, Ar-H), 7.74 (4H, brs, NH, $\mathrm{D}_{2} \mathrm{O}-$ exchangable); ${ }^{13} \mathrm{C}$ NMR $\left(75 \mathrm{MHz}, \mathrm{DMSO}-d_{6}\right): \delta 82.2$, 127.4, 127.8, 128.2, 138.7, $161.2(\mathrm{C}=\mathrm{O})$; Anal. Calcd for $\mathrm{C}_{16} \mathrm{H}_{14} \mathrm{~N}_{4} \mathrm{O}_{2}$ : C, 65.30; H, 4.79; N, 19.04. Found: C, $65.17 ; \mathrm{H}, 4.86 ; \mathrm{N}, 18.87$.

2.1b 5-Hydroxy-1-methyl-4,5-diphenyl-1H-imidazole2(5H)-one (table 2, entry 2): Yield $0.20 \mathrm{~g}$ (78\%), m.p $>300^{\circ} \mathrm{C}, \mathrm{IR}\left(\mathrm{KBr}, \mathrm{cm}^{-1}\right)$ : 1691, 1726, 2883, 2953, 3092, $3203(\mathrm{OH}) ;{ }^{1} \mathrm{H}$ NMR $\left(300 \mathrm{MHz}, \mathrm{DMSO}-d_{6}\right)$ : $\delta 2.52\left(3 \mathrm{H}, \mathrm{s}, \mathrm{CH}_{3}\right), 6.76-7.12(10 \mathrm{H}, \mathrm{m}, \mathrm{Ar}-\mathrm{H}), 8.46$ $\left(1 \mathrm{H}\right.$, brs, $\mathrm{OH}, \mathrm{D}_{2} \mathrm{O}$-Exchangable); ${ }^{13} \mathrm{C}$ NMR $(75$ $\left.\mathrm{MHz}, \mathrm{DMSO}-d_{6}\right): \delta 25.9,83.6,127.7,128.2,128.3$, 128.6, 128.7, 135.5, 159.5, 160.1; Anal. Calcd for $\mathrm{C}_{16} \mathrm{H}_{14} \mathrm{~N}_{2} \mathrm{O}_{2}$ : C, 72.16; H, 5.30; N, 10.52. Found: C, $72.02 ; \mathrm{H}, 5.41 ; \mathrm{N}, 10.46$.

2.1c 4,5-Dihydroxy-1,3-dimethyl-4,5-diphenylimidazolidine-2-one (table 2, entry 3): Yield $0.24 \mathrm{~g}(83 \%)$, m.p: $220-222^{\circ} \mathrm{C}$, IR $\left(\mathrm{KBr}, \mathrm{cm}^{-1}\right): 1664,2793,2928$, 2989, 3171, 3420; ${ }^{1} \mathrm{H}$ NMR $\left(300 \mathrm{MHz}, \mathrm{DMSO}-d_{6}\right)$ : $\delta 2.56\left(6 \mathrm{H}, \mathrm{s}, 2 \times \mathrm{CH}_{3}\right), 6.58\left(2 \mathrm{H}\right.$, brs, $\mathrm{OH}, \mathrm{D}_{2} \mathrm{O}-$ exchangable), 6.89-7.01 (10H, m, Ar-H); ${ }^{13} \mathrm{C}$ NMR $\left(75 \mathrm{MHz}\right.$, DMSO- $\left.d_{6}\right): \delta$ 26.0, 92.8, 127.3, 127.7, 127.8, 138.0, 160.1; Anal. Calcd for $\mathrm{C}_{17} \mathrm{H}_{18} \mathrm{~N}_{2} \mathrm{O}_{3}$ : C, 68.44; H, 6.08; N, 9.39. Found: C, 68.56; H, 5.97; N, 9.47.

2.1d 5-Hydroxy-1,4,5-triphenyl-1H-imidazole-2(5H)one (table 2, entry 4): Yield 0.24g (75\%), m.p > $300^{\circ} \mathrm{C}$, IR (KBr, cm $\left.{ }^{-1}\right): 1691,1724,3041,3063,3340$; ${ }^{1} \mathrm{H}$ NMR $\left(300 \mathrm{MHz}, \mathrm{DMSO}-d_{6}\right): \delta 6.86-7.26(15 \mathrm{H}$, $\mathrm{m}$, Ar-H), $8.81\left(1 \mathrm{H}\right.$, brs, OH, $\mathrm{D}_{2} \mathrm{O}$-Exchangable); ${ }^{13} \mathrm{C}$ NMR $\left(75 \mathrm{MHz}, \mathrm{DMSO}-d_{6}\right): \delta$ 104.1, 125.4, 127.0, 127.7, 127.9, 128.4, 129.0, 129.3, 132.3, 135.4, 137.2, 159.1, 159.8; Anal. Calcd for $\mathrm{C}_{21} \mathrm{H}_{16} \mathrm{~N}_{2} \mathrm{O}_{2}$ : C, 76.81; H, 4.91; N, 8.53. Found: C, 76.68; H, 4.80; N, 8.70.

2.1e 1-Benzyl-5-hydroxy-4,5-diphenyl-1H-imidazole2(5H)-one (table 2, entry 5): Yield $0.26 \mathrm{~g}(76 \%)$, m.p: 283-285 ${ }^{\circ} \mathrm{C}$, IR $\left(\mathrm{KBr}, \mathrm{cm}^{-1}\right): 1689,1714,2872,2926$, 3065,$3205 ;{ }^{1} \mathrm{H}$ NMR $\left(300 \mathrm{MHz}, \mathrm{DMSO}-d_{6}\right): \delta 3.89$ $\left(1 \mathrm{H}, \mathrm{dd}, J=16.7 \mathrm{~Hz}, \mathrm{CH}_{2}\right), 4.37(1 \mathrm{H}, \mathrm{dd}, J=16.7 \mathrm{~Hz}$, $\left.\mathrm{CH}_{2}\right), 6.66-7.32(15 \mathrm{H}, \mathrm{m}, \mathrm{Ar}-\mathrm{H}), 8.42(1 \mathrm{H}, \mathrm{brs}, \mathrm{OH}$, $\mathrm{D}_{2} \mathrm{O}$-Exchangable); ${ }^{13} \mathrm{C}$ NMR $\left(75 \mathrm{MHz}\right.$, DMSO- $\left.d_{6}\right)$ : $\delta$ 45.1, 90.6, 126.9, 127.5, 128.0, 128.3, 128.4, 128.6, 129.1, 133.3, 137.5, 139.4, 159.4, 160.6; Anal. Calcd for $\mathrm{C}_{22} \mathrm{H}_{18} \mathrm{~N}_{2} \mathrm{O}_{2}$ : C, 77.17; H, 5.30; N, 8.18. Found: C, 77.30; H, 5.20; N, 8.10.

2.1f 4,5-Diphenyl-1H-imidazole-2-thiol (table 2, entry 6): Yield $0.17 \mathrm{~g}(68 \%), \mathrm{m} . \mathrm{p}>300^{\circ} \mathrm{C}, \mathrm{IR}\left(\mathrm{KBr}, \mathrm{cm}^{-1}\right)$ : 1209, 1498, 1674, 2748, 3013, 3161; ${ }^{1} \mathrm{H}$ NMR $\left(300 \mathrm{MHz}, \mathrm{DMSO}-d_{6}\right): \delta$ 7.33-7.35 $(10 \mathrm{H}, \mathrm{m}, \mathrm{Ar}-$ $\mathrm{H}), 12.54\left(2 \mathrm{H}\right.$, brs, NH, SH (Tautomerization), $\mathrm{D}_{2} \mathrm{O}-$ Exchangable); ${ }^{13} \mathrm{C}$ NMR (75 MHz, DMSO- $\left.d_{6}\right): \delta 125.2$, 127.9, 128.6, 128.8, 129.2, 160.4; Anal. Calcd for $\mathrm{C}_{15} \mathrm{H}_{12} \mathrm{~N}_{2} \mathrm{~S}:$ C, 71.40; H, 4.79; N, 11.10; S, 12.71. Found: C, 71.31; H, 4.85; N, 11.01; S, 12.80 .

2.1g 1-Methyl-4,5-diphenyl-1H-imidazole-2-thiol (table 2, entry 7): Yield 0.16g (63\%), m.p: $194-196^{\circ} \mathrm{C}$, IR $\left(\mathrm{KBr}, \mathrm{cm}^{-1}\right)$ : 1273, 1493, 1599, 2752, 2910, 2937, 3049; ${ }^{1} \mathrm{H}$ NMR (300 MHz, DMSO- $\left.d_{6}\right): \delta 3.29(3 \mathrm{H}, \mathrm{s}$, $\left.\mathrm{CH}_{3}\right), 7.23-7.48(10 \mathrm{H}, \mathrm{m}, \mathrm{Ar}-\mathrm{H}), 12.82(1 \mathrm{H}, \mathrm{brs}, \mathrm{SH}$, $\mathrm{D}_{2} \mathrm{O}$-Exchangable); ${ }^{13} \mathrm{C}$ NMR (75 MHz, DMSO- $\left.d_{6}\right): \delta$ 32.2, 124.6, 126.8, 127.3, 128.0, 128.6,128.9, 129.2, 129.6, 129.8, 131.1, 161.9; Anal. Calcd for $\mathrm{C}_{16} \mathrm{H}_{14} \mathrm{~N}_{2} \mathrm{~S}$ : C, 72.15; H, 5.30; N, 10.52; S, 12.04. Found: C, 72.01; H, 5.39; N, 10.48; S, 12.15; MS (m/z, \%): $266\left(\mathrm{M}^{+}\right)$, $165,136,118,97,83,69,57(100)$. 
2.1h Tetrahydroimidazo[4,5-d]imidazole-2,5(1H,3H)dione (table 2, entry 9): Yield $0.10 \mathrm{~g}(70 \%)$, m.p $>$ $300^{\circ} \mathrm{C}$, IR (KBr, cm $\left.{ }^{-1}\right): 1701,1763,2843,3074,3223$; ${ }^{1} \mathrm{H}$ NMR $\left(300 \mathrm{MHz}, \mathrm{DMSO}-d_{6}\right): \delta 5.23(2 \mathrm{H}, \mathrm{s}, 2 \times$ $\mathrm{CH}), 7.18$ (4H, brs, NH, $\mathrm{D}_{2} \mathrm{O}$-Exchangable); ${ }^{13} \mathrm{C}$ NMR $\left(75 \mathrm{MHz}, \mathrm{DMSO}-d_{6}\right): \delta$ 65.0, 161.7; Anal. Calcd for $\mathrm{C}_{4} \mathrm{H}_{6} \mathrm{~N}_{4} \mathrm{O}_{2}$ : C, 33.81; H, 4.26; N, 39.42. Found: C, 33.94; H, 4.12; N, 39.52.

2.1i 5-Hydroxy-1-phenyl-1H-imidazole-2(5H)-one (table 2, entry 10): Yield $0.12 \mathrm{~g}$ (72\%), m.p $>300^{\circ} \mathrm{C}$, IR $\left(\mathrm{KBr}, \mathrm{cm}^{-1}\right): 1705,1730,2874,3103,3211 ;{ }^{1} \mathrm{H}$ NMR $\left(300 \mathrm{MHz}, \mathrm{DMSO}-d_{6}\right): \delta 6.05(1 \mathrm{H}, \mathrm{s}, \mathrm{CH}), 7.08-7.58$ $(6 \mathrm{H}, \mathrm{m}, \mathrm{Ar}-\mathrm{H}), 8.53$ (1H, brs, $\mathrm{OH}, \mathrm{D}_{2} \mathrm{O}-$ Exchangable); ${ }^{13} \mathrm{C}$ NMR $\left(75 \mathrm{MHz}, \mathrm{DMSO}-d_{6}\right): \delta 65.6,119.6,123.5$, 129.2, 138.4, 157.2; Anal. Calcd for $\mathrm{C}_{9} \mathrm{H}_{8} \mathrm{~N}_{2} \mathrm{O}_{2}$ : C, 61.36; H, 4.58; N, 15.90. Found: C, 61.47; H, 4.51; N, 16.01 .

2.1j 1-Benzyl-5-hydroxy-1H-imidazole-2(5H)-one (table 2, entry 11): Yield $0.14 \mathrm{~g}(77 \%)$, m.p $>300^{\circ} \mathrm{C}$, IR $\left(\mathrm{KBr}, \mathrm{cm}^{-1}\right): 1695,1700,2856,2941,3032,3115$, $3221 ;{ }^{1} \mathrm{H}$ NMR $\left(300 \mathrm{MHz}, \mathrm{DMSO}-d_{6}\right): \delta 3.99(1 \mathrm{H}$, $\left.\mathrm{dd}, J=15.5 \mathrm{~Hz}, \mathrm{CH}_{2}\right), 4.55(1 \mathrm{H}, \mathrm{dd}, J=15.5 \mathrm{~Hz}$, $\left.\mathrm{CH}_{2}\right), 5.04(1 \mathrm{H}, \mathrm{s}, \mathrm{CH}), 7.25-7.36(6 \mathrm{H}, \mathrm{m}, \mathrm{Ar}-\mathrm{H}), 7.81$ (1H, brs, $\mathrm{OH}, \mathrm{D}_{2} \mathrm{O}-$ Exchangable); ${ }^{13} \mathrm{C}$ NMR $(75 \mathrm{MHz}$, DMSO- $\left.d_{6}\right): \delta 43.6,65.3,127.6,128.1,128.9,137.8$, 159.3, 160.4; Anal. Calcd for $\mathrm{C}_{10} \mathrm{H}_{10} \mathrm{~N}_{2} \mathrm{O}_{2}$ : C, 63.15; H, 5.30; N, 14.73. Found: C, 63.28; H, 5.22; N, 14.86.

$2.1 \mathrm{k}$ Tetrahydro-3a-methyl-6a-propylimidazo[4,5-d] imidazole-2,5(1H,3H)-dione (table 2, entry 12): Yield $0.12 \mathrm{~g}(68 \%)$, m.p $>300^{\circ} \mathrm{C}$, IR $\left(\mathrm{KBr}, \mathrm{cm}^{-1}\right)$ : 1680 , 1724, 2887, 2980, 3250; ${ }^{1} \mathrm{H}$ NMR (300 MHz, DMSO$\left.d_{6}\right): \delta 0.93\left(3 \mathrm{H}, \mathrm{t}, J=7.1 \mathrm{~Hz}, \mathrm{CH}_{3}\right), 1.32(3 \mathrm{H}, \mathrm{s}$, $\left.\mathrm{CH}_{3}\right), 1.62\left(2 \mathrm{H}, \mathrm{q}, J=7.1 \mathrm{~Hz}, \mathrm{CH}_{2}\right), 7.09(2 \mathrm{H}$, brs, $\mathrm{NH}, \mathrm{D}_{2} \mathrm{O}$-Exchangable), $7.20(2 \mathrm{H}$, brs, $\mathrm{NH}$, $\mathrm{D}_{2} \mathrm{O}$-Exchangable); ${ }^{13} \mathrm{C}$ NMR (75 MHz, DMSO- $\left.d_{6}\right)$ : $\delta$ 8.0, 21.9, 28.5, 75.9, 78.2, 160.1; Anal. Calcd for $\mathrm{C}_{8} \mathrm{H}_{14} \mathrm{~N}_{4} \mathrm{O}_{2}$ : C, 48.47; H, 7.12; N, 28.26. Found: C, $48.61 ; \mathrm{H}, 7.00 ; \mathrm{N}, 28.42$.

2.11 1H-phenanthro [9, 10-d] imidazole-2-thiol (table 2, entry 13): Yield $0.16 \mathrm{~g}(64 \%), \mathrm{m} . \mathrm{p}>300^{\circ} \mathrm{C}$, IR $(\mathrm{KBr}$, $\left.\mathrm{cm}^{-1}\right)$ : 1195, 1502, 1620, 2759, 2946, 3165; Anal. Calcd for $\mathrm{C}_{15} \mathrm{H}_{10} \mathrm{~N}_{2} \mathrm{~S}$ : C, 71.97; H, 4.03; N, 11.19; S, 12.81. Found: C, 72.24; H, 4.16; N, 10.98; S, 12.77.

$2.1 \mathrm{~m}$ 1-Methyl-1H-phenanthro [9, 10-d] imidazole2-thiol (table 2, entry 14): Yield $0.15 \mathrm{~g}$ (60\%), m.p $>300^{\circ} \mathrm{C}, \mathrm{IR}\left(\mathrm{KBr}, \mathrm{cm}^{-1}\right): 1116,1487,1537,1612$, 2752, 2945, 3078, 3138; Anal. Calcd for $\mathrm{C}_{16} \mathrm{H}_{12} \mathrm{~N}_{2} \mathrm{~S}: \mathrm{C}$, 72.70; H, 4.58; N, 10.60; S, 12.13. Found: C, 72.93; H, $4.41 ; \mathrm{N}, 10.46 ; \mathrm{S}, 12.31$.

\section{Results and discussion}

During the course of our study aiming at improving the ecocompatibility of certain organic processes, ${ }^{24}$ we have been particularly interested in the development of organic transformations in the presence of $\mathrm{TMSCl}$ catalyst. Here, we report the reaction of benzil $\mathbf{1}$ and urea/thiourea derivatives for the formation of title compound at $100^{\circ} \mathrm{C}$ in the presence of catalytic amount of TMSCl under solvent-free conditions (scheme 1).

In order to determine the most appropriate reaction conditions, the condensation reaction of benzil 1 ( $1 \mathrm{mmol}$ ) with urea 2 ( $1 \mathrm{mmol})$ was carried out in different solvents and solvent-free in the presence of TMSCl. The results are shown in table 1 . The best results were obtained with $10 \mathrm{~mol} \%$ of catalyst under solvent-free conditions (SFC) at $100^{\circ} \mathrm{C}$ and gave $4,4^{\prime}$-diphenyl glycoluril 3 without formation of any by-products. When we examined this condensation under SFC between benzil and urea with molar ratio 1:1, the corresponding product yield was only $45 \%$, again we repeated this reaction with molar ratio $1: 1.5$, but we observed a significant increase in the corresponding yield (72\%) (table 1, entry 6). We also condensed benzil and urea with molar ratio $1: 2$, respectively but the yield of product was only $74 \%$. In the case of the other $\alpha$-diketone derivatives, this condensation was carried out between $\alpha$-diketone compounds and urea/thiourea derivatives (table 2, entries 2-14) with molar ratio 1:2, 1:1.5 and $1: 1$, respectively but the yield of products was slightly differed from each other (for example, in entry 2, condensation of $\mathrm{N}$-methyl urea and benzil was carried out with molar ratio 1:1, 1:1.5, 1:2 and the product of entry 2 was formed with $75 \%, 78 \%$ and $79 \%$ yields, respectively). So, we decided to do all reactions with molar ratio 1:1.5 between $\alpha$-diketone compounds and urea/thiourea derivatives.

After optimization of reaction conditions, we examined the generality of this procedure for other substrates using $\alpha$-diketone compounds and urea/thiourea derivatives (table 2). In the case of the urea derivatives such as $\mathrm{N}$-methyl urea, N-benzyl urea, $\mathrm{N}, \mathrm{N}^{\prime}$-dimethyl urea and $\mathrm{N}$-phenyl urea with $\alpha$-diketone, the major product was not a glycoluril derivative and the product was imidazolidine-2-one or imidazole-2-one (table 2, entries $2-5,10,11)$. So, the major product for reaction 


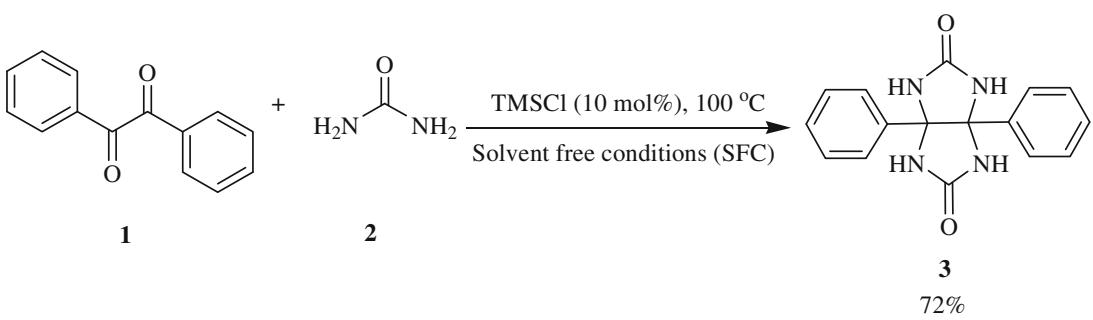

Scheme 1. Condensation of benzil and urea with molar ratio 1:1.5.

Table 1. Optimization of reaction conditions.

\begin{tabular}{|c|c|c|}
\hline Entry & Conditions & Yield $^{\mathrm{a}}(\%)$ \\
\hline 1 & EtOH, Reflux, TMSCl (10 mol \%), 4h & 48 \\
\hline 2 & THF, Reflux, TMSCl (10 mol \%), 4h & 0 \\
\hline 3 & $\mathrm{CHCl}_{3}$, Reflux, TMSCl (10 mol \%), 4h & 26 \\
\hline 4 & $\mathrm{CH}_{3} \mathrm{CN}$, Reflux, TMSCl $(10 \mathrm{~mol} \%), 4 \mathrm{~h}$ & 0 \\
\hline 5 & $\mathrm{SFC}, 100^{\circ} \mathrm{C}, \mathrm{TMSCl}(10 \mathrm{~mol} \%)$, benzil:urea (1:1), $30 \mathrm{~min}$ & 45 \\
\hline 6 & $\mathrm{SFC}, 100^{\circ} \mathrm{C}, \mathrm{TMSCl}(10 \mathrm{~mol} \%)$, benzil:urea $(1: 1.5), 30 \mathrm{~min}$ & 72 \\
\hline 7 & $\mathrm{SFC}, 100^{\circ} \mathrm{C}, \mathrm{ChCl} .2$ urea $(0.3 \mathrm{~mL}), 30 \mathrm{~min}$ & 32 \\
\hline 8 & $\mathrm{SFC}, 100^{\circ} \mathrm{C}, \mathrm{ChCl} .2$ urea $(0.3 \mathrm{~mL}), \mathrm{TMSCl}, 30 \mathrm{~min}$ & 70 \\
\hline 9 & $\mathrm{SFC}, 100^{\circ} \mathrm{C}$, benzil:urea $(1: 1.5)$, Catalyst free, $3 \mathrm{~h}$ & 0 \\
\hline
\end{tabular}

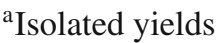

Table 2. Condensation of urea/thiourea derivatives and $\alpha$-diketone compounds.

Entry Urea derivatives Yield(\%)


Table 2. (continued).

\section{Entry}

5<smiles>NC(=O)NCc1ccccc1</smiles><smiles>O=C(C(=O)c1ccccc1)c1ccccc1</smiles><smiles>O=C1N=C(c2ccccc2)C(O)(c2ccccc2)N1Cc1ccccc1</smiles><smiles>O=C(C(=O)c1ccccc1)c1ccccc1</smiles><smiles>Sc1nc(-c2ccccc2)c(-c2ccccc2)[nH]1</smiles><smiles>NC(N)=S</smiles><smiles>O=C(C(=O)c1ccccc1)c1ccccc1</smiles><smiles>Cn1c(S)nc(-c2ccccc2)c1-c1ccccc1</smiles><smiles>CNC(N)=S</smiles><smiles>O=C(C(=O)c1ccccc1)c1ccccc1</smiles><smiles>O=C1NC2NC(=O)NC2N1</smiles><smiles>NC(N)=O</smiles><smiles>O=CC=O</smiles><smiles>O=C1N=CC(O)N1c1ccccc1</smiles><smiles>NC(=O)Nc1ccccc1</smiles><smiles>O=CC=O</smiles><smiles>NC(=O)NCc1ccccc1</smiles><smiles>O=CC=O</smiles><smiles>O=C1N=CC(O)C1NCc1ccccc1</smiles>

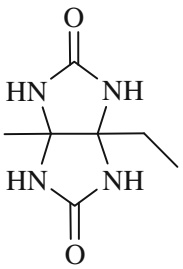


Table 2. (continued).

Entry Urea derivatives Product

of thiourea and $\mathrm{N}$-methyl thiourea with $\alpha$-diketone was imidazole-2-thiol (table 2, entries 6,7,13,14), and in the case of the N,N'-diphenyl thiourea condensation with benzil did not observe any reaction (table 2, entry 8).

Also, we have carried out this reaction in the presence of $\mathrm{ChCl}$.2urea ionic liquid as one of deep eutectic solvents (DESs) at $100^{\circ} \mathrm{C}$ with the same molar ratio but product yield was only $32 \%$ (table 1, entry 7 ), again, reaction was carried out in the presence of both TMSCl and ChCl.2urea (table 1, entry 8), we observed that product yield was increased to $70 \%$. From this, we concluded that in addition to added urea to benzil, urea in $\mathrm{ChCl}$.2urea ionic liquid in the presence of TMSCl reacts with benzil and this increases the efficiency of product. We carried out the condensation of benzil and other derivatives of urea such as $\mathrm{N}$-methyl urea $\mathbf{4}$ and $\mathrm{N}, \mathrm{N}^{\prime}$-dimethyl urea $\mathbf{5}$ under the same conditions in entry 8 , but the only product was $4,4^{\prime}$-diphenyl glycoluril 3. On the other hand, we found that reactivity of the urea in $\mathrm{ChCl}$.2urea is more than urea derivatives (scheme 2).

On the basis of the experimental results, probable mechanism for the synthesis of title compounds is shown in scheme 3. Initially, $\mathrm{TMSCl}$ catalyst as
Lewis acid activates the carbonyl groups of benzil, then nucleophilic attack of the nitrogen urea or thiourea derivatives to the activated carbonyl groups of benzil produced intermediate $\mathbf{I}$. When $\mathrm{R}, \mathrm{R}^{\prime}=\mathrm{H}$, the reaction can proceed through the in situ formation of unstable compound II by water elimination, which is further attacked by a second molecule of urea to give compound III. Comparing the structures of urea derivatives (when $\mathrm{R}=\mathrm{H}, \mathrm{R}^{\prime}=\mathrm{Ph}, \mathrm{PhCH}_{2}, \mathrm{CH}_{3}$ or $\mathrm{R}, \mathrm{R}^{\prime}=\mathrm{CH}_{3}$ ) and of the corresponding products, it can be seen in all the cases that, these derivatives of compounds IV, $\mathbf{V}$ produced, which in this state due to existence steric hindrance of alkyl or aryl group in $\mathbf{I V}, \mathbf{V}$, the reaction pathway could not be further proceeded. ${ }^{25}$

When thiourea was condensed with benzil, probably at first step, via water elimination, compound VI formed in this state, thiourea as reducing agent one of the $\mathrm{C}=\mathrm{N}$ band, produced compound VII, finally by water elimination from VII, the corresponding product as thiol or thione was produced. Probably thiourea via hydrolysis converted to urea and hydrogen sulfide $\left(\mathrm{H}_{2} \mathrm{~S}\right)$, which $\mathrm{H}_{2} \mathrm{~S}$, via reduction of $\mathrm{C}=\mathrm{N}$ band produces intermediate VII and finally by water elimination from VII, aromatic stable compound VIII produced. ${ }^{26}$

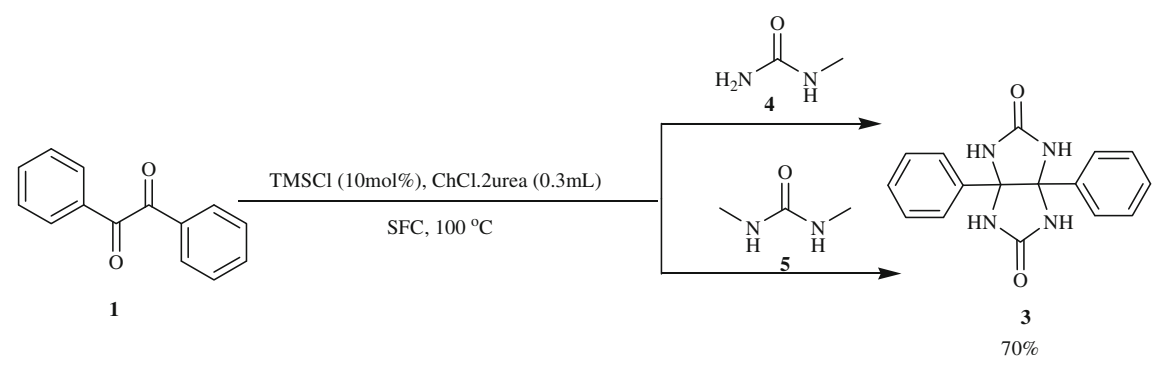

Scheme 2. Reactivity of urea in $\mathrm{ChCl}$.2urea ionic liquid and its derivatives with benzil. 


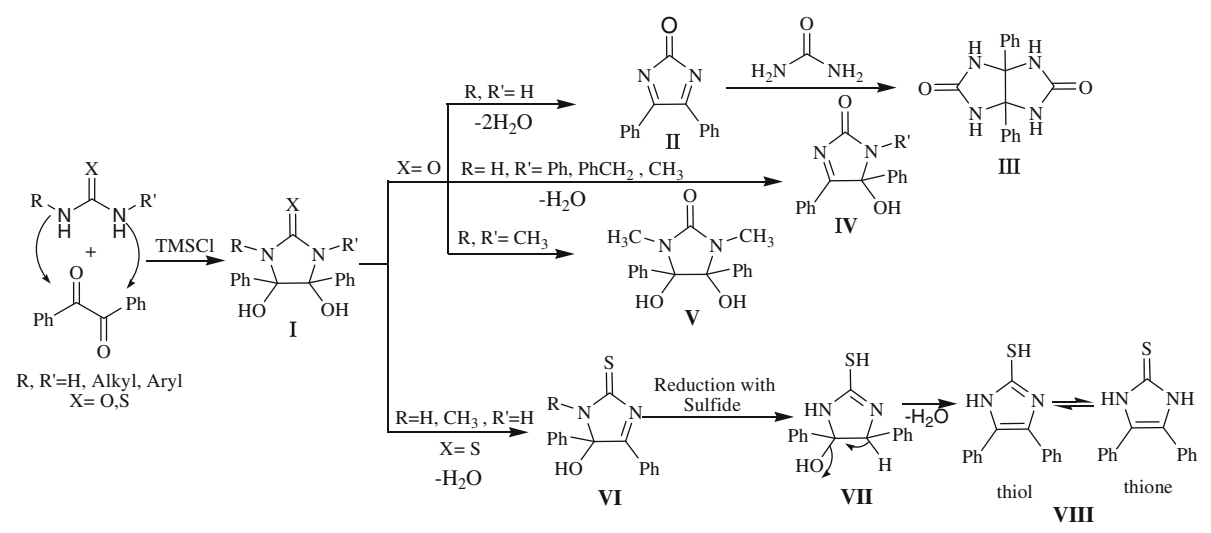

Scheme 3. Probable mechanism for condensation of benzil and urea or thiourea derivatives.

\section{Conclusion}

In summary, we have successfully developed a simple, green and highly efficient one-pot synthesis of glycoluril, imidazolidine-2-one, imidazole-2-one and imidazole-2-thiol compounds from easily available starting materials using TMSCl (trimethylsilyl chloride) as a Lewis acid catalyst under solvent-free conditions. For the first time, we have prepared each of these compounds under the same conditions. This protocol is attractive in terms of: atom economy, short reaction time, simple and clean reaction profiles, easy work-up and various products.

\section{Supplementary information}

Supplementary data (experimental details and spectroscopic characterization $\left({ }^{1} \mathrm{H}\right.$ and $\left.{ }^{13} \mathrm{C}-\mathrm{NMR}\right)$ of the compounds) are available through the journal website (www.ias.ac.in/chemsci).

\section{Acknowledgements}

We acknowledge the financial support received from the Research Council of Arak University.

\section{References}

1. (a) Mashkovskii M D 2002 Lekarstvennye sredstva (Drugs), vol. 1, Novaya Volna, Moscow. 39 86; (b) Saloutina L V, Zapevalov A Y, Saloutin V I, Slepukhin P A, Mikhail I, Kodess M I and Chupakin O N 2009 J. Fluorine. Chem. 130853

2. (a) Rheineck H 1865 Liebigs. Ann. Chem. 134 219; (b) Stancl M, Khan M S A and Sindelar V 2011 Tetrahedron 678937

3. Nicholas J M, Liu Y, Zavalij P, Isaacs L and Doyle M P 2008 Inorg. Chim. Acta 3613309
4. (a) Li J T, Liu X R and Sun M X 2010 Ultrason. Sonochem. 17 55; (b) Muccioli G G, Poupaert J H, Wouters J, Norberg B, Poppitz W, Scribad G K E and Lambert D M 2003 Tetrahedron 591301

5. Wu A, Fettinger J C and Isaacs L 2002 Tetrahedron 58 9769

6. Congiu C, Cocco M T and Onnis V 2008 Bioorg. Med. Chem. Lett. 18989

7. Pryor K E and Rebek J 1999 Org. Lett. 139

8. Slezak F B, Bluestone H, Magee T A and Wotiz J H 1962 J. Org. Chem. 272181

9. Beyer A, Reucher C M M and Bolm C 2011 Org. Lett. 132876

10. McLaughlin M, Palucki M and Davies I W 2006 Org. Lett. 83311

11. Kidawi M, Kukreja S, Rastogi S and Singhal K 2007 Indian J. Chem. Sect B. 4615499

12. Dawood K M and Abdel-Wahab B F 2010 Chem. Heterocycl. Compd. 46255

13. Burnett C A, Lagona J, Wu A, Shaw J A, Coady D, Fettinger J C, Day A I and Isaacs L 2003 Tetrahedron 59 1961

14. Slezak F B, Hirsch A and Rosen I 1960 J. Org. Chem. 25660

15. Zeng R S, Zou J P, Zhi S J, Chen J and Shen Q 2003 Org. Lett. 51657

16. Singh C B, Murru S, Kavala V and Patel B K 2006 Org. Lett. 85397

17. (a) Özkay Y, Işıkdağ İ, İncesu Z and Akalın G 2010 Eur. J. Med. Chem. 45 3320; (b) Maduskuie T P, Wilde R G, Billheimer J T, Cromley D A, Germain S, Gillies P J, Higley C A, Johnson A L, Pennev P, Shimshick E J and Wexler R R 1995 J. Med. Chem. 381067

18. Vasilevskii S V, Nelyubina Y V and Kravchenko A N 2009 Mendeleev. Commun. 19279

19. Rezaei-Seresht E and Tayebee R 2011 J. Chem. Pharm. Res. 3103

20. Baranov V V, Nelyubina Y V, Kravchenko A N and Makhova N N 2010 Russ. Chem. Bull. 591427

21. Baranov V V, Gazieva G A, Nelyubina Y V, Kravchenko A N and Makhova N N 2011 Russ. J. Org. Chem. 47 1564

22. Sachin G M, Mehta V P, Ermolat'ev D, Balzarini J, Heck K V, Meervelt L V and Eycken E V 2010 Mol. Divers. 14767 
23. Bosman W P, Beurskens P T, Admiraal G, Sijbesma R P and Nolte R J M Z 1991 Kristallografiya 197305

24. Zendedel M, Mobinikhaledi A and Hasanvand J F 2007 J. Inclus. Phenom. Mol. Recogn. Chem. 59 41; (b) Azizi N, Khajeh Amiri A R, Ghafuri H, Saidi M R and Bolourtchian M 2010 J. Iran Chem. Soc. 7 428; (c) Wang H-Y and Shi D-Q 2012 J. Heterocyclic. Chem. 49212
25. Micheletti G, Delpivo C and Baccolini G 2013 Green. Chem. Lett. Rev. 6135

26. (a) Gilman H and Dickey J B 1930 J. Am. Chem. Soc. 52 4573; (b) Menche D, Hassfeld J, Li J, Menche G, Ritter A and Rudolf S 2006 Org. Lett. 8 741; (c) Osunlaja A A, Idris S O and Lyun J F 2012 Int. J. Chem. Tech. Res. 4609 